\title{
Diagnosing Homicidal Mania: Forensic Psychiatry and the Purposeless Murder
}

\author{
JOEL PETER EIGEN*
}

Dear Mr. Shaw-I received your letter on last Tuesday. I think I will get hung, but I do not care as long as I get a good breakfast before they hang me. If they do not hang me I think I will commit suicide. That will do just as well. I will strangle myself. I hope you are well. I go up on Monday to the Old Bailey to be tried, I hope you will be there. I think they will sentence me to die. If they do I will call all the witnesses liars. I remain

Yours affectionately,

R A Coombes

It is not every criminal defendant in late Victorian England who writes to the medical officer of the prison, inviting him to attend his trial and more than likely, his execution. The defendant had already discussed his forthcoming date at the Old Bailey with the prison doctor in a mood that bordered on ebullience: "he appeared in very great glee at being about to be ... tried ... he thought it would be a splendid sight ... he said he would wear his best clothes and have his boots well polished - then he began to talk about his cats". It might seem odd to shift the conversation so easily from a possible death sentence to asking about one's pets, but then, thirteen-year-old boys are often concerned about their pets, even thirteen-year-old boys who conspire with a younger brother to murder their mother and leave her body to rot for a week.

Testifying at the trial of the young defendant in September 1895, the prison medical officer told the jury that the boy's note had been accompanied by a series of illustrated panels:

Then followed a drawing of a gibbet and two figures being pushed forward by another; over the last figure was written, "Executioner." That was headed, "Scene 1, going to the Scaffold." Then "Scene II", a drawing of a gibbet with a person being hanged and the words, "Goodbye" issuing from his mouth, and the writing, "Here goes nothing!" ... "P.S. Excuse the scaffold, I was too heavy. I bent it."

In wide-ranging testimony that spanned organic to functional causes of insanity, the physician informed the court, "There is a distinct scar on his right temple, and on very careful examination I noticed also a very faint scar just in front of his left ear-those scars might have been caused by instruments used at the time of his birth ... I asked him whether he heard voices - he said at night he heard voices saying 'kill her, kill her, and run away',", which is exactly what young Robert Coombes did after his younger brother Nathaniel gave

C) Joel Peter Eigen 2010

* Prof. Joel P Eigen, Department of Sociology,

Franklin \& Marshall College, PO Box 3003,
Lancaster, PA 17604-3003, USA; e-mail:

joel.eigen@fandm.edu 


\section{Joel Peter Eigen}

him the signal that the time was right to stab their mother. As his reason for the murder, the boy cited his fear "that if he did not do so, she would kill his younger brother [since] she had threatened to knock his brains out with a hatchet [having] thrown knives at him".

The focus of the medical witness's testimony was not the boy's difficult delivery and likely "brain compression", but his gleeful expectation about the forthcoming trial: "whilst in prison he never appeared to realise his position, or showed remorse for the crime he had committed". The medical witness ascribed the boy's seeming moral obliviousness, and the likely consequence of his act, to a mysterious disease that, by the end of the nineteenth century, had grown in acceptance to rival the most frequently cited reasons given by medical witnesses as grounds for inferring insanity. As the jury learned,

There are two forms of homicidal mania: sometimes the crime is committed on the impulse of the moment; sometimes with great deliberation and cunning ... I have been studying criminal lunacy more or less for the last twenty-three years-in my opinion these symptoms will be characteristic of the boy during his life.

Under cross-examination, the medical officer of Holloway addressed the supposedly sane elements that surrounded the deranged assault: "I seriously mean that he would go to the shop, select the knife, bargain for it, and buy it while under the influence of mania; under the influence of homicidal mania these crimes are done with great deliberation." Asked specifically by the judge to describe the mental state accompanying such an attack of this particular mania, the doctor answered, "the person would not know the nature and quality of the act he was doing" or "the difference between right or wrong". Whether it was the scars on the boy's temples, the family doctor testifying to his history of "irresistible impulses", or indeed the diagnosis of homicidal mania that the prison doctor proffered, thirteen-yearold Robert Coombes was never to glimpse the scaffold he drew with such artistic flair. Eventually found guilty but insane for the brutal slaying of his mother, he was detained indefinitely "awaiting the Queen's pleasure".

Although one might be tempted to dismiss the case of young Robert Coombes as anomalous in the day-to-day calendar at the Old Bailey-thirteen-year-old boys rarely faced trial for murder, and rarer still, for the killing of a parent-invoking homicidal mania to characterize the defendant's particular species of insanity revealed a qualitative change in the language of nineteenth-century descriptive psychopathology. For the first time in a 150 -year effort to fashion medical condition to legal criterion, the Old Bailey jury would be faced with a diagnosis of insanity that inserted homicide into its own name.

\section{Mental Medicine and Inexplicable Crime}

The vivid testimony given in the trial of this young defendant can be found in an invaluable series of courtroom narratives, taken down in shorthand as the trial was progressing, transcribed at night, and sold on the London street the next day. They remain the most comprehensive primary material that today's historians of law and medicine are ever likely to have of the language used by medical men and lay witnesses to describe their observations of the prisoner's behaviour and to justify the grounds for inferring mental aberrancy. Making

${ }^{1}$ Old Bailey Sessions Papers (hereafter OBSP), 1895, case 720, 11th sess., pp. 996-1018. 


\section{Diagnosing Homicidal Mania}

their appearance in 1674 and printed continuously until 1913, The Old Bailey Sessions Papers (hereafter $O B S P$ ) are a critical source for capturing the texture of courtroom dynamics. They offer not only the voice of the emerging specialist in mental medicine but also the language employed by the judge, attorney, lay witness, and jurors who occasionally questioned the medical witness directly. In some trials, the most audible voice belongs to the prisoner himself, who obstinately demanded that the physician justify his reasons for finding him mad. ${ }^{2}$

Although medical men were long familiar to the London courtroom in their capacity as specialist witnesses to advise the jury on the timing and cause of death, their participation in trials featuring an insanity plea dates only to $1760 .^{3}$ Given that the first acquittal on the grounds of "unsound mind" was recorded in 1505, medical witnesses appearing to argue the presence of insanity found themselves in a forum that was accustomed to relying upon the recollections of the prisoner's relatives and neighbours who, the common law had long assumed, were in the best position to recount the verbal pandemonium and frightening histrionics of the accused. ${ }^{4}$ Unlike a victim of stabbing found with no blood in her wounds or a drowned man whose lungs "gave no water", there seemed little need for the services of a Fellow of the Royal College of Physicians to decipher the conspicuous, indeed theatrical signs of florid mental derangement. In the eighteenth century, Roy Porter has famously written, madness was "spectacularly on view ... doubts about nature's legibility troubled few". 5

Porter's observation is supported by the $O B S P$, which reveal that an eighteenth-century mad doctor faced a more daunting task than the toxicologist or the general practitioner: he had to convince the jury that lay perceptions of madness could be misleading because the non-specialist, fooled by surface impressions, lacked the broad experience and sustained familiarity with the universe of the mentally deranged to "persist in the interview". ${ }^{6}$ In time,

\footnotetext{
${ }^{2}$ In 1813 , a medical witness was compelled to respond to a prisoner's query calling for the grounds for his inference of insanity. The apothecary to St Luke's Hospital replied, "From your action, and ideas, and your general conduct told me that you were an improper person to be at liberty." The prisoner responded sharply, "You judge from ideas; you have a good opinion of yourself." OBSP, 1813, case 11, 1st sess., p. 14. In the trial of Hugh Pollard Willoughby, the allegedly mad prisoner extracted from the prison surgeon, Gilbert McMurdo, an admission that if the prisoner's construction of the events were accurate, he could not be described as suffering from a delusion $(O B S P, 1854$, case 1122 , 12th sess., pp. 1361-71). For the historical importance of the $O B S P$ for reconstructions of the courtroom, see John H Langbein, 'The criminal trial before the lawyers', Univ. Chicago Law Rev., 1978, 45: 263-316, and idem, 'Shaping the eighteenth-century criminal trial: a view from the Ryder sources', Univ. Chicago Law Rev., 1983, 50: 1-136.

${ }^{3}$ Nigel Walker, Crime and insanity in England, vol. 1, The historical perspective, Edinburgh University Press, 1968. Walker credits the testimony of John Monro, Physician Superintendent of Bedlam at the 1760 trial of Earl Ferrers as the first time a
}

medical witness appeared in an English trial to speak to insanity as a medical condition, pp. 60-2.

${ }^{4}$ For the date of the 1505 acquittal, "the felon was of unsound mind ... [w] [werefore it was decided that he should go free", see Walker, op. cit., note 3 above, pp. 25-6. On the common law's reliance upon lay witnesses, see Joel P Eigen, Witnessing insanity: madness and mad-doctors in the English court, New Haven, Yale University Press, 1995, pp. 82-107.

${ }^{5}$ Roy Porter, Mind-forg'd manacles: a history of madness in England from the Restoration to the Regency, Cambridge, MA, Harvard University Press, 1987, p. 35.

${ }^{6}$ The apothecary and author John Haslam famously observed in 1817, "Ordinary persons have been much deceived by the temporary display of rational discourse ... [but] ... the experienced will ... find by some unaccountable association, even ordinary topics are linked to- the madman's darling delusions - the map of his mind will point out that the smallest rivulet flows into the great stream of his derangement", Medical jurisprudence, as it relates to insanity: according to the laws of England, London, C Hunter, J Hunter and Taylor and Hessey, 1817, pp. 15-19. 
the trial narratives reveal an increasingly confident voice and self-possessed professional posture on the part of the nineteenth-century alienists—often at the prompting of attorneys and judges. ${ }^{7}$ Coincident with this assertive professional bearing was the witness's use of innovative disease classifications, found in late Victorian medical texts and journals in both England and France, which were making their way into the London courtroom as well.

In the 153 years that separated the first trial in which medical witnesses appeared at the Old Bailey to testify about insanity as a medical condition (1760) and the year that the Papers cease publication (1913), some form of mental distraction surfaced in the prosecution of 1,008 prisoners, the majority raising insanity in their defence, the remainder being found unfit to plead. The years from 1760 to 1843 and from 1844 to 1876 have already been examined with regard to medical diagnoses given to the jury, changes in professional affiliation of medical witnesses, and the continuing efforts of the new specialists in mental medicine to enlarge the scope of the law's conception of insanity and, in response, the law's steadfast refusal to accept ever more expanding bases to pronounce irresponsibility. ${ }^{8}$ The focus of this lively debate turned on one overriding issue: whether medical testimony would continue to confine itself to opinions regarding an impairment of the cognitive facultiesknowing the nature of one's acts, knowing the difference between right and wrong-or whether jury deliberations would move beyond intellectual error to consider a derangement in emotions: an affective insanity.

Beginning with Philippe Pinel's proffered neologism, manie sans délire, and continuing into a second generation of disease entities put forward by his students Jean-EtienneDominique Esquirol and Etienne-Jean Georget, asylum doctors and medical writers in the first half of the nineteenth-century proposed the existence of a clear-thinking insanity capable of impelling the deranged into desperate acts, quite beyond their voluntary control. ${ }^{9}$ England's most vocal proponent of such derangement in affect was James Cowles Prichard, whose formulation "moral insanity" described a species of insanity in which

the intellectual faculties appear to have sustained little or no injury ... the moral and active principles of the mind are strangely perverted and depraved; the power of self government is lost or greatly impaired, and the individual is found to be incapable, not of talking or reasoning upon any subject proposed, for this he will often do with great shrewdness and volubility, but of conducting himself with decency and propriety in the business of life. ${ }^{10}$

A derangement of feelings, temper, and habit provided the conceptual home for irresistible and uncontrollable impulses, which entered Old Bailey testimony through the diagnoses

\footnotetext{
${ }^{7}$ Joel P Eigen, “'I answer as a physician”: opinion as fact in pre-McNaughtan insanity trials', in Michael Clark and Catherine Crawford (eds), Legal medicine in history, Cambridge University Press, 1994, pp. 167-99.

${ }^{8}$ For the years $1760-1843$, see Eigen, op. cit., note 4 above. The years 1844 to 1876 are examined in Joel P Eigen, Unconscious crime: mental absence and criminal responsibility in Victorian London, Baltimore, Johns Hopkins University Press, 2003.
}

\footnotetext{
${ }^{9}$ On Pinel's announced discovery of "paroxysms of maniacal fury, unaccompanied by any lesion of the intellect", see Philippe Pinel, A treatise on insanity, transl. D D Davis, Sheffield, W Todd, 1806, pp. 152-4. For an analysis of the contributions of Georget and Esquirol more generally to the school of médecine mentale, see Jan Goldstein, Console and classify: the French psychiatric profession in the nineteenth century, Cambridge University Press, 1987.

${ }^{10}$ James Cowles Prichard, A treatise on insanity, London, Sherwood, Gilbert, and Piper, 1835, p. 5.
} 


\section{Diagnosing Homicidal Mania}

of moral insanity and "lesion of the will". ${ }^{11}$ That they found their way into the London courtroom most conspicuously in the trial of Edward Oxford for an attempted assassination of the Queen ensured both public and juridical consideration of the possible significance of a derangement of morals for the attribution of criminal responsibility. ${ }^{12}$ Oxford's eventual acquittal prompted the court's interest in clarifying as soon as possible the law's position regarding the necessary and sufficient type of derangement for the purposes of the common law, taking only three years to find a case with which to articulate the enduring grounds for an insanity defence. Known as the McNaughtan Rules, the criteria resulting from the controversial 1843 acquittal conspicuously excluded any mention of moral insanity, lesion of the will, or impulsive derangement. Insanity would remain, as far as the English court was concerned, a matter of intellectual derangement: a perversion of the knowing faculties most frequently revealed in delusion. ${ }^{13}$ First articulated in court in 1800 , delusion served not only as the distinguishing element between lay and medical testimony but also as the most frequently invoked medico-legal term cited by early-nineteenth-century mad doctors to justify the inference of insanity. ${ }^{14}$

The effort on the part of the common law judges to restrict the grounds for a jury's finding of insanity and, by extension, the scope of medical testimony plays out dramatically in the pages of the Old Bailey narratives. Having gained a foothold in the courtroom by the time of McNaughtan-medical witnesses were by the mid-1840s appearing in nine of ten insanity trials prompted by a personal assault — these new courtroom specialists were not so easily muzzled. The McNaughtan Rules, so confidently invoked in the legal literature as the criteria that would serve to define insanity, were in fact rarely mentioned at the Old Bailey in the decades following their formation. ${ }^{15}$ The centrality of cognitive error to the law's conception of insanity, however, endured into successive nineteenth-century trials. Asylum doctors and alienists who veered into language that touched on moral insanity were met

${ }^{11}$ Eigen, op. cit., note 4 above, pp. 149-53. "Lesion of the will" was addressed specifically by Esquirol in his effort to articulate the variations of monomania. "In a third class of cases, a lesion of the will exists. The patient is drawn ... to the commission of acts, to which neither reason nor sentiment determine, which conscience rebukes, and which the will has no longer the power to restrain. The actions are involuntary, instinctive, and irresistible. This is monomania without delirium, or, instinctive monomania." J E D Esquirol, Mental maladies; a treatise on insanity, transl. E K Hunt, Philadelphia, Lea and Blanchard, 1845, p. 320.

${ }^{12}$ OBSP, 1840, case 1877,9 th sess., pp. 464-510. For the political context in which the Oxford trial took place, see Richard Moran, 'The punitive uses of the insanity defense: the trial for treason of Edward Oxford (1840)', Int. J. Law Psychiatry, 1986, 9: 171-90.

${ }^{13}$ McNaughtan's trial can be found at $O B S P$, 1842-43, case 874, 5th sess., pp. 721-63. The McNaughtan Rules resulted from the questions asked by the House of Lords of the judges in the celebrated trial, to be found in McNaughtan Case, 10 Clark and
Finnelly, pp. 203-14. Reactions from contemporary jurists can be found in Richard Moran, Knowing right from wrong: the insanity defense of Daniel

McNaughtan, New York, Free Press, 1981, see esp. pp. 168-75.

${ }^{14}$ Joel P Eigen, 'Delusion in the courtroom: the role of partial insanity in early forensic testimony', Med. Hist., 1991, 35: 25-49.

${ }^{15}$ Although the McNaughtan Rules provided criteria for judicial instructions, neither the Court of Crown Cases Reserved nor indeed any other English court delivered a definitive ruling regarding the relationship of insanity to criminal responsibility. McNaughtan's status as an authoritative ruling was "doubtful" according to the most esteemed jurist of the era, James Fitzjames Stephen. In part this was because the nature of insanity was argued anew at every trial. Assertions to expertise were proffered; judges, attorneys, and juries reacted in ways that had more to do with the particular elements of the offence than with the formal legal strictures. See James Fitzjames Stephen, A history of the criminal law of England, 3 vols, London, Macmillan, 1883, vol. 2, p. 153. 


\section{Joel Peter Eigen}

with judges who interrupted their testimony to ask: "Has she any delusion at all?"16 In print, physicians bristled at the law's "constricted" view of insanity; in court, medical witnesses balked at questions that restricted their testimony to intellectual derangement. ${ }^{17}$ Still, it was a legal, not a medical forum in which asylum physicians and general practitioners found themselves. A review of courtroom testimony in the decades following McNaughtan reveals the near disappearance of moral insanity and irresistible impulse from Old Bailey trials. The possibility of a discrete derangement of affect, however, remained a lively topic of debate in the medical literature.

Although delusion continued to characterize the common law's notion of an appropriate basis for an insanity plea in the second half of the nineteenth century, the decades immediately following McNaughtan were notable for the introduction of extraordinary states of consciousness - or rather, unconsciousness-in courtroom testimony. Sleepwalkers, automatons, and persons afflicted with a peculiar variation of epilepsy began to appear at the Old Bailey from the midpoint of the 1800s. Vertige épileptique featured in medical testimony from 1876, introduced initially during the tragic case of a mother who had entered her kitchen with her infant daughter in her hands, intending to slice off a piece of bread. Once in the kitchen, Elizabeth Carr descended into a state of mental suspension, described by French clinicians as a period of absence separating two convulsive seizures. Persons in this state might carry on a conversation or perform feats of remarkable dexterity, but following a second convulsion, they "came to" only to discover that whatever was said or done in the intervening minutes was lost to them. In this episode of dissociation, Elizabeth Carr had sliced off her daughter's hand and was eventually placed on trial for assault with intent to murder.

Together with the other courtroom participants, the pitiable mother listened as Dr Edward Merrion, physician to the Hospital for Diseases of the Nervous System, explained the features of vertige épileptique, concluding, "it is not looked upon by [my] profession as insanity in any form". Rejecting all possible findings open to them, the jurors fashioned their own basis for an acquittal: not guilty on the grounds of unconsciousness. The verdict shocked the court and outraged the judge, who promptly refused to release the prisoner, electing to treat the jury's finding as equivalent to an insanity acquittal and called for the defendant's indefinite detention. ${ }^{18}$ Still, epileptic vertigo had unambiguously entered the English courtroom, and not for this one trial only. Six months after the tragic mother had been acquitted (but detained), another prisoner enlisted epileptic vertigo in a perplexing, totally unprovoked fatal assault on his best friend. ${ }^{19}$ At the conclusion of the trial, the judge asked the jury to consider if the prisoner had "labour[ed] under such an affliction of Providence that he was for the moment deprived of consciousness to such an extent that

\footnotetext{
${ }^{16}$ For examples, see $O B S P, 1849-50$, case 1300 , 9th sess.; $O B S P, 1851-52$, case 572,7 th sess.; $O B S P$, 1866-67, case 912, 11th sess. The centrality of delusion to law can be found in both legal and medical opinion. See, respectively, Stephen, op. cit., note 15 above, and Alfred Swaine Taylor: "The acts of the insane generally arise from motives based on delusion", in The principles and practice of medical jurisprudence, London, J Churchill, 1865, p. 1106.

${ }^{17}$ Some medical authors had long been contemptuous of the elevation of delusion as the sole
}

\author{
criterion for inferring insanity. "Is deluded \\ imagination a significant characterization for the \\ naked wanderer? [T] hose who recover describe it no \\ otherwise than a total suspension of every rational \\ faculty", John Monro, Remarks on Dr. Battie's \\ treatise on madness, London, John Clarke, \\ 1758 , p. 6. \\ ${ }^{18}$ OBSP, $1875-76$, case 413,11 th sess., pp. 495-7. \\ ${ }^{19}$ The Times, 9 Feb. 1877 , p. 5f. The trial of \\ Frederick Treadaway can be found at $O B S P, 1876-77$,
} case 246, 4th sess., pp. 434-60. 


\section{Diagnosing Homicidal Mania}

he was a mere automaton from an attack of epileptic vertigo". ${ }^{20}$ Two years later, a judge in Scotland incorporated a similar state of unconsciousness in his instructions to a jury during a trial that featured the horrific killing of an adored young boy by his sleepwalking father. $^{21}$

Crimes of the unconscious were not instances of moral insanity. Defendants who put forward extraordinary states of mental functioning were not alleging a derangement of habits, sentiments, or feelings. There was nothing "clear headed" about their criminality; if anything, they were missing at their own crime, lending perhaps a very vivid image to the term "absence". And yet, the two types of mental distraction shared a feature that would pose a continuing conundrum for Old Bailey juries: inexplicable, pointless, indeed self-annihilating criminality. Moral insanity might serve as a plausible explanation in cases where there had been no object to the crime at all. "I might as well shoot at her as anyone else", sighed Queen Victoria's soi-disant assassin, which is hardly a cri de coeur from a defendant likely to pay for his regicide with a state execution. ${ }^{22}$

\section{When Criminality Becomes a Diagnosis}

In an effort to examine how the late Victorian courts responded to seemingly purposeless criminality committed after the 1876 acquittal on the grounds of unconsciousness, an examination was undertaken of all trials heard at the Old Bailey from 1877 to 1913, the year that the Papers cease publication. The survey yielded a total of 478 trials in which some form of mental derangement was put forward as part of the prisoner's defence. Seventy-five indicted persons were determined unfit to plead, leaving a total of 403 prisoners who eventually entered some form of insanity in their defence. Medical witnesses testified in almost all of these trials, although it was still possible for a defendant in late Victorian England to be declared insane with no asylum doctor, police surgeon, or general practitioner advising the jury whatsoever. Indeed, it was possible for a jury to acquit on the grounds of insanity or, after 1883 , to find a defendant "guilty, but insane" without the prisoner ever raising the plea. $^{23}$

To support their inference of mental derangement, medical witnesses invoked a broad array of psychological and material agents, ranging from hallucinations to hypochondriasis,

${ }^{20}$ HM Adv. v. Fraser (1878), 4 Couper 78: 70-78.

${ }^{21}$ The medical witness published his own review of the trial and the grounds for inferring unconsciousness. Dr Yellowlees, 'Homicide by a somnambulist', J. Men. Sci., 1878, 24: 451-8.

${ }^{22}$ Joel P Eigen, 'Sense and sensibility; arsenic and insanity in nineteenth-century England', in R A Melikan, Maureen Mulholland, and Brian Pullan (eds), The trial in history: politics, crime, and the state 1699-1900, Manchester University Press, 2003, pp. 21-35.

${ }^{23}$ The wording of the insanity acquittal was the subject of parliamentary action in 1883 , prompted by a request from the palace following a third assassination attempt on the Queen. Since madmen were likely to respond to the idée fixe of their delusion, the palace averred, could not the fear of conviction also work on their mind? Although both verdicts yielded the same disposition-indefinite detention awaiting the sovereign's pleasure-a finding of "guilty but insane" was conceived to function as a deterrent, even for the deluded. For an analysis of the political context in which the 1883 Act took hold, see Joel P Eigen, “"An inducement to morbid minds": politics and madness in the Victorian courtroom', in Markus D Dubber and Lindsay Farmer (eds), Modern histories of crime and punishment, Stanford University Press, 2007, pp. 66-87. 


\section{Joel Peter Eigen}

Table 1

Medical terms cited in testimony (by trial)

\begin{tabular}{lc}
\hline Term & Frequency \\
\hline Delusion & 96 \\
Melancholia & 46 \\
Homicidal mania & 43 \\
Epilepsy & 36 \\
Melancholy & 23 \\
Hallucinations & 13 \\
Unconscious & 12 \\
Mania & 12 \\
Puerperal insanity & 11 \\
Brain disorder & 6 \\
\hline
\end{tabular}

coup de soleil to coma, paralytic stroke to paroxysm. Table 1 lists the most frequently invoked terms mentioned in insanity trials by medical witnesses in the late nineteenth and early twentieth centuries. ${ }^{24}$ As witnessed in the two periods that precede this survey (1760-1843 and 1844-1876), delusion continues to feature most prominently in Old Bailey medical testimony bearing on mental derangement. Judges ask about it, defence lawyers frame questions around it, and prisoners often mention it either in their statements before the arraigning magistrate or at their trial. Melancholia, a term that had all but disappeared in courtroom testimony of the first half of the nineteenth century-although never having fallen into desuetude in the popular culture-made a striking reappearance at the Old Bailey. ${ }^{25}$ Together with mania, melancholia has enjoyed perhaps the longest vintage in western conceptions of madness, dating to classical antiquity. ${ }^{26}$ Similarly, epilepsy and puerperal insanity, well represented in this list, were often heard in court earlier in the century as well.

\footnotetext{
${ }^{24}$ Table 1 lists only the most frequently cited terms; many others were mentioned by medical witnesses, but as the focus of the present work is the salience of key terms employed by forensic-psychiatric witnesses as measured by the frequency of their appearance, only those terms mentioned six or more times were included. It should also be noted that these terms were often mentioned in connection with one another; delusion and melancholia might appear together, melancholy and puerperal insanity could similarly be described by the same witness. The separation of melancholy (a disposition) from melancholia (a disease entity) follows the distinctions drawn in courtroom testimony. Clearly it is possible that melancholy and melancholia were used interchangeably by some witnesses, yet they were usually treated separately in both medical text and medical testimony. Further, there were cases
}

in which no causal agent was given; medical witnesses merely characterized the prisoner as "depressed" or of "unsound mind".

${ }^{25}$ In his effort to bring nineteenth-century descriptive psychopathology in line with evolving clinical, scientific medicine, Esquirol sought to free mental derangement from traditional humoral grounding. He retained melancholia's association with an idée fixe, but replaced the spectre of a sorrowful disposition with an expansive, indeed, explosive temperament. The resulting term, monomanie, featured instinctive and homicidal variants.

${ }^{26}$ For a comprehensive historical analysis of melancholia, both in medical and cultural context, see Stanley W Jackson, Melancholia and depression: from Hippocratic times to modern times, New Haven, Yale University Press, 1986. 


\section{Diagnosing Homicidal Mania}

There is one term, however, which came into prominence in this latest survey, that had rarely been mentioned earlier at the Old Bailey and stood apart even from delusion and melancholia in its relation to crime. By the early twentieth century, homicidal maniaand its brethren, homicidal tendency and homicidal impulse-had surpassed puerperal insanity, brain injuries, and epilepsy to rank only behind delusion and melancholia as the most frequently cited grounds supporting a diagnosis of severe mental impairment. Where it distinguished itself - even among the more familiarly invoked conditions-was in its defining, inevitable consequence. One could be delusional and end one's days profoundly yet harmlessly paranoid; one could descend into the depths of melancholia and sit year-byyear simpering by the fire contemplating suicide. Only homicidal mania had a necessary objective: murder. Medical men who cited the prison interview as the basis for their inference of insanity did not have to look far to ground their diagnosis in the contemporary medical literature.

One notes an intriguing connection between the medical text quoted most frequently in courtroom testimony and the case material employed by its author to justify homicidal mania's niche in the jurisprudence of insanity. In its fourth edition already at the time of the trials surveyed in this study, Alfred Swaine Taylor's The principles and practice of medical jurisprudence (1865) was quoted verbatim both by defence lawyers posing questions and by medical witnesses supplying the grounds for their diagnosis. Taylor's totemic text outlined the three forms homicidal mania could take: the propensity to kill related to an actual delusion, an absurd motive to kill related to no known motive, or an impulse to kill that was "sudden, instantaneous, unreflective, and uncontrollable" ${ }^{27}$ Even when the author and his work were not invoked by name, the adjectives just mentioned—recited in seriatim—could be heard in court. In the 1902 trial of Amelia Wieland for the wilful murder of her daughter, the medical witness concluded his direct testimony with "I agree that one of the degrees of homicidal mania is where the impulse to kill is sudden, unresisting, unreflective, and uncontrollable". ${ }^{28}$

As useful as Taylor's volume would prove to medical witnesses trying to argue the case for homicidal mania in court, it is difficult to see how Medical jurisprudence would have taken shape-or continued to merit its numerous editions-without the day-today trials at the Old Bailey. One discovers in his text not only the prominent cases of Oxford, Hadfield, and McNaughtan, but the somewhat less celebrated insanity trials of deluded Robert Pate (1850), sleepwalker Sarah Minchin (1853), and housewife Ann Vyse (1862), who mixed Battle's Vermin Killer into the ingredients for her children's rice pudding. ${ }^{29}$ A conspicuous synergy existed therefore between medical text and medical testimony, each supplying the other with legitimacy and illustration, in a reciprocal bond of co-dependence.

When the medical witness in the Wieland trial employed Taylor's construction of homicidal mania as uncontrollable impulse, neither the notion of overwhelming compulsion nor the idea of an unruly impulse was new to the Old Bailey. What was new-both in medical testimony and medical writing - was the particular use of the term, unreflective. One would have thought that an impulse said to bypass the reflective powers of mind left little room

\footnotetext{
${ }^{27}$ Taylor, op. cit., note 16 above, pp. 1101-2.

${ }^{28}$ OBSP, 1902-03, case 113,2 nd sess., pp. 228-33.
} 


\section{Joel Peter Eigen}

for the possibility that delusion could ever play a role in homicidal mania. ${ }^{30}$ But even as medical witnesses spoke in terms of "impulsive homicidal tendency", almost half placed delusion at the heart of this curious malady. In a critical move, the specialist witness was articulating the vital component of delusion that, although never negotiated in court, would invest the diagnosis with penetrating courtroom effect.

\section{Delusion's Unnamed Hook}

When delusion was first introduced to the English court in 1800 at the trial of James Hadfield —introduced, one might add, by a the defence lawyer, not a medical witness-it was clear that a profound fear or overwhelming presentiment did not merely languish in one's mind. Delusion carried a powerful spur to action. Believing that one's execution at the hands of the state would replicate the death of Jesus and thereby usher in the Second Coming compelled the true believer to act. ${ }^{31}$ Mothers who feared that Satan would capture and kill their children unless they killed them first did not merely ponder this conviction. As juries in the first half of the nineteenth century learned, "nothing short of a physical impossibility would prevent him from performing any act which his delusion might impel him to do". ${ }^{32}$ Delusive beliefs and fears dictated behavioural acts that bypassed the actor's capacity to choose. That the inevitable consequence of delusion was rarely mentioned in courtroom testimony is not surprising. Determinism in any form-whether psychological or organic-was anathema to the law's basis for ascribing culpability: purposefully chosen behaviour. And yet the acquittal of defendants described as delusional suggests the jury's acknowledgement that circumscribed error and the consequent behavioural spur had placed the act beyond the defendant's volition. By grounding homicidal mania upon delusion, medical witnesses were creating a familiar conceptual home for this most recent form of impulsive, unreflective insanity.

Even when not invoked by name, medical witnesses at the Old Bailey often included the imagery commonly associated with delusion. Jurors learned that as a form of circumscribed derangement, homicidal mania left the afflicted seemingly capable of conducting all other features of their life, even as they were driven to crime. Imagery long associated with overpowering fear and dread was therefore employed in court:

a power of darkness overshadowed him, the idea came to him that he had better kill the children, that they may go to a better world ... not unfrequently persons in a fit of homicidal mania will kill the persons near and dear to them other than strangers. ${ }^{33}$

\footnotetext{
${ }^{30}$ Contemporary scientific literature explained the phenomenon of behaviour unattended by thought with the concept of reflexes: the "ideo-motor principle of action" put forward by Carpenter, who argued that an idea could act directly on motor processes, bypassing the mental processes of reflection and volition. See William B Carpenter, The doctrine of human automatism: a lecture, London, Sunday Lecture Society, 1875, and Thomas Laycock, 'Reflex, automatic, and unconscious cerebration: a history and a criticism', J. Men. Sci., 1876, 21: 477-98. Popular entertainments including music hall hypnotism and salon mesmerism also demonstrated the possibility of
}

behaviour unattended by consciousness. For a comprehensive history of these cultural diversions, see Alison Winter, Mesmerized: powers of mind in Victorian Britain, University of Chicago Press, 1998.

${ }^{31}$ Defence attorneys could also enlist delusion as the agent of the prisoner's crime. In 1812, a medical witness stated, "the old delusion, acting on his mind, will lead him to do any act", $O B S P, 1812$, case 527 , 6th sess., p. 333.

${ }^{32}$ OBSP, 1842-43, case 874, th sess., p. 761.

${ }^{33}$ OBSP, 1898, case 621, 11 th sess., p. 1171. 


\section{Diagnosing Homicidal Mania}

The association of delusion with a dark shadow on the mind dates to classical antiquity, picked up by Renaissance medicine's focus on the role of melancholic humours extruding black adust in the brain, and continuing into the trial of Daniel McNaughtan: "I mean that black spot on his mind." 34 Overshadowing darkness had found a new home in the late Victorian insanity trial: this time, in homicidal mania. ${ }^{35}$

It fell to Henry Charlton Bastian, physician to the Hospital for the Paralyzed and Epileptic, to supply the most comprehensive courtroom explanation of homicidal mania when asked by a judge to give his medical opinion of what lay behind the illogical crime.

A man having certain tendencies will occasionally without warning or provocation, commit a certain act of violence, sometimes suicidal, sometimes homicidal; something comes over him abruptly ... leading him to commit some act of violence, he being absolutely unconscious of the act; he may know what it is, but not the quality of it. [A] gust of impulse comes over him so suddenly that he is not in a position to weigh or balance whether such a thing is right or wrong ... ${ }^{36}$

The doctor's effort to distinguish the prisoner's capacity to know the nature but not the quality of the act - that it was legally wrong but not morally wrong-drew the conceptual world of homicidal mania and delusion even closer. James Hadfield's delusion that he must sacrifice himself by killing George III meant that the defendant was fully mindful that his act was legally proscribed-indeed he chose it because it would ensure his execution-but that the delusion regarding his saving mankind by his own execution left him oblivious to its moral transgression. Given such profound confusion, could his act be described as wilful, as chosen? Deluded people were fully capable of describing the events surrounding their offence, but, given a fateful misreading of the consequences of their behaviour, they were incapable of appreciating what was wrong about the act.

After Dr Bastian gave his expansive definition of homicidal mania, he was asked pointedly: "How would it be consistent with the prisoner's not being conscious of the act that the man, an hour afterwards, would say to the surgeon at the hospital, 'Have I finished the job? Is she dead? If not, I am sorry for it'." The medical witness acknowledged the difficulty of the question, and answered in the following, admittedly equivocal, way:

[W] don't know the workings of his mind at the time- that sort of thing occurs again and again in these homicidal acts. It may be some sudden thought that compels him irresistibly ... for some time the notion may linger in his mind - the only question is whether the notion is a thing generated in his sane mind or in the mind of a man who is insane-I feel the difficulty fully; and I can go no further than saying, "It is possible"; I cannot affirm it more distinctly.

That Bastian had been asked by the Treasury to visit the prisoner in his cell and was in court to serve as the Crown's rebuttal witness to the defence case may have contributed to his reluctance to pronounce unambiguously on the prisoner's state of mind. Still, his testimony supplied the jury with the connection between diagnosis and behaviour, affirmed by another witness for the prosecution, the medical officer of Holloway: "I agree with Dr Bastian that

${ }^{34}$ OBSP, 1842-43, case 874, 5th sess., p. 763.

35 "Overshadowing darkness" would return later in the century during the trial of Mary Ann Brough, to be discussed shortly. Brough's trial was among the first to enlist homicidal mania as the grounds for an insanity defence.

${ }^{36}$ OBSP, 1895-96, case 504, 9th sess., p. 881. 


\section{Joel Peter Eigen}

it is possible that the man may have suffered from a sudden attack of homicidal mania at the time the act was committed." 37

If one reads Bastian's comments carefully, it is possible to see how impulsive, even irresistible criminality was being placed at the doorstep of a notion lingering in the accused's mind. This was the essence of delusional insanity, further underscoring how much had changed with the introduction of delusion as the first substantive challenge to a total want of memory and understanding as the requisite criterion for acquittal. Defendants who raised an insanity plea in the 1700 s had been depicted as delirious, insensible, "being out of one's wits"- a degree of distraction almost mandated by the reigning legal criterion articulated in "wild beast" imagery since the Arnold case in 1725. ${ }^{38}$ With the successful introduction of a partial state of derangement at the Hadfield trial (1800), medical testimony affirmed the capacity of the delusional to execute a range of tasks on the day of the crime, revealing nothing even to their intimates.

In time, the capacity to function within a circumscribed mental world was extended to homicidal mania. Testifying in 1879 , a physician asserted: "I do not think that the making of arrangements or the disposition of property ... is inconsistent with the fact of a person suffering from homicidal mania", adding, perhaps a bit provocatively, "a person who is insane is not deprived of mind". ${ }^{39}$ Expert witnesses often picked up on this theme, stressing the "great deliberation and cunning" that would attend the act of the homicidal maniac. Although such testimony veered perilously close to premeditation and hence to the law's central tenet of intention - what the actor meant to do, what he chose to do-juries appeared willing to consider the possibility that seemingly purposeful behaviour could be unattended by conscious choice owing to an overwhelming homicidal impulse animated by a delusion.

Again, the notion of an all-powerful impulse propelling the accused into an outrageous act of violence was not new to the court, but it had yet to find receptive ears among judges or juries. Unlike the earlier species of moral insanity defined by deficiencies of volitional control even as the accused had been fully aware of the nature of his crime, homicidal mania managed to engage the law's central concern with knowing right from wrong by framing the mania as the impulsive response to a delusory fear: a "shadow" on the mind. This was not mere mania that might lead to aggression or brutality; it was a propensity to kill: as Taylor had written, "an impulse to kill". ${ }^{40}$ Still, a judge had only to ask the medical witness how he would distinguish an irresistible from an unresisted (homicidal) impulse, as he was wont do to when confronted with expert testimony featuring uncontrollable impulses. "What does criminality imply, but that passion has got the mastery of reason-that the importunity of temptation is too clamorous to allow the voice of reason to be heard. What is this but the subjugation of reason to vice?"41 Although homicidal mania accompanied by delusion met no discernible hostility on the part of the judiciary, not all defendants could avail themselves of the law's chosen mental impairment. When it was not on offer,

\footnotetext{
${ }^{37}$ Ibid., p. 882.

${ }^{38}$ For lay images transported to the courtroom, see Eigen, op. cit., note 4 above, pp. 82-105.

${ }^{39}$ OBSP, 1879-80, case 428, 7th sess., p. 103.

${ }^{40}$ This language was picked up in criminal trials as well: "a tendency ... to child murder" $(O B S P$, 1879-80, case 428, 7th sess., p. 101; an "uncontrollable impulse to kill" (OBSP, 1887-88,
}

case 407,6 th sess., p. 800 ); "impulse to take a life" (OBSP, 1900-1, case 142, 3rd sess., p. 199; OBSP, 1910, case 366, July, p. 378).

41 'Baron Rolfe's charge to the jury in the case of boy Allnutt, who was tried at the central criminal court for the murder of his grandfather, on the 15th of December, 1847', J. Psych. Med. Men. Path., 1848, 1: 193-216. 


\section{Diagnosing Homicidal Mania}

courtroom testimony reveals an attempt to couple homicidal mania with another malady, already associated with autonomous forces that could carry the afflicted "quite away".

\section{A Convulsion of Ideas}

Then something seemed to snap in my head and I jumped up and caught her by the throat... . I felt as if I was holding a very strong galvanic battery ... I wanted to leave go and I could not. When I did leave go she fell. I realised almost in a moment what I had done.... I held a mirror to her mouth to see if she was breathing, and she was not. ${ }^{42}$

Although it was not unusual for eighteenth-century insanity defendants to offer a Prisoner's Defence at their trial, the construction of a comprehensive role for the defence lawyer after the Prisoner's Counsel Act of 1836 usually meant that future allegedly mad prisoners would be silent during their trial. ${ }^{43}$ William Philpot, however, would prove the exception, beginning his defence with the above graphic description of the killing. He was followed in the witness box by a police surgeon, who spoke to the prisoner's state of mind when he checked to see if his wife was breathing after the brutal attack. "One of the characteristics of a person who is subject to such fits when the fit is not on is to be perfectly rational. After a fit they usually go to sleep, and on waking appear quite normal." The type of fit the prisoner was subject to, the police surgeon explained, was epilepsy. But it was a novel form of this long-familiar disease that jurors were to learn about from Sidney Dyer, Medical Officer at Brixton:

Persons having epileptic tendencies may discharge the ordinary duties of life quite normally for years without the brain showing any weakness of the kind, and when subject to attack give way to uncontrolled fury. When the attack has passed over they appear quite cool and collected. This is called epileptic automatism. ... I found no epileptic tendencies in the prisoner, though he was closely watched. It would be possible for him, however, not to betray them. Of all classes of weakness masked epilepsy is the one form which is so often concealed in a person. ${ }^{44}$

There was certainly nothing novel in drawing epilepsy into insanity's orbit or in coupling it with automatism; this had already been effected in 1876 during the prosecution of the mother who fatally injured her infant in a state of epileptic vertigo. What was noteworthy in Dr Dyer's testimony was his use of "masked epilepsy", which by the early twentieth century was increasingly associated with homicidal mania. First articulated in France in an effort to parcel out states of epileptiform disorders in terms of degree of impairment, this "silent" form of the disease, capable of generating violently assaultive behaviour, was named l'épilepsie larvée by Bénédict-Augustin Morel and Jean-François Falret. Masked, or larval, epilepsy had attracted the attention of theorists and clinicians because of its widely believed connection to murderous fury. Described as sudden, without motive, and noteworthy for

\footnotetext{
${ }^{42}$ OBSP, 1912, Jan., p. 577.

${ }^{43}$ Defence attorneys were only given a scope of advocacy that we normally associate with this role today-addressing the jury, summing up evidence, actually pleading a defence-with the Trial for Felonies Act of 1836, commonly referred to as the Prisoner's Counsel Act. Before this, defence attorneys were routinely restricted to questioning witnesses.
} 
its ferocity, the fatal assault of the (masked) epileptic was committed in plain sight with no attempt to hide or elude detection. ${ }^{45}$

In England, masked epilepsy could not have found a more influential voice than that of Henry Maudsley, editor of the Journal of Mental Science from 1860 to 1878, and a frequent witness at the Old Bailey. Unambiguously claiming his intention "to group the reported cases of homicidal mania to exhibit the relations of them as morbid states of the nervous system", Maudsley found in masked epilepsy both an organic grounding for involuntary behaviour and a ready explanation for why those afflicted had never revealed the traditional motor disturbances associated with epilepsy prior to the crime. Epilepsy had been hiddenmasked - by the seemingly normal functioning of the prisoner up to the moment when a "convulsion of ideas" took hold, propelling the afflicted into murderous assault. ${ }^{46}$

Forms of masked epilepsy varied. In some patients "the character of the disease changed; instead of epileptic attacks the afflicted was seized with an irresistible impulse to commit murder". ${ }^{47}$ In other cases, epileptic seizures produced criminal assault from their inception. In the witness box, medical witnesses explained that the prisoner's particular form of epilepsy had substituted crime for convulsion: "in place of the fit, there is an overwhelming anxiety to commit a crime", or "it is a disease in which the fact of epilepsy is replaced by an impulse to do some outrageous homicidal act". ${ }^{48}$ One divisional police surgeon distinguished masked epilepsy by explaining: "In masked epilepsy, there is not the frothing at the mouth or the twitching of arms or limbs." 49 Two years later, a prison medical officer continued in this vein: "there is no outward sign, there is no convulsion or apparent loss of consciousness - the patient does not fall down". ${ }^{50}$ Undetected by even the patient's intimate associates and sometimes even unnoticed by the afflicted themselves, persons suffering from masked epilepsy could find themselves the accidental offender in a crime that remained as much a mystery to them as it did to the jury. Such was the tragic tale of Ernest Partridge in 1910.

Standing over his dead wife, the prisoner had realized to his horror what had immediately transpired. A medical man who had been called to the crime scene informed the jury of his conversation with the prisoner.

He then said that he remembered absolutely nothing else until he heard a knock and the shout "Milk. 3d. a quart." He then suddenly came to himself, and discovered that ... his wife ... was dead with her throat cut. He became very excited ... and said to me, "Doctor, if that milkman had only shouted 'Milk, 3d. a quart' one minute before my dear wife's life would have been saved," which I considered very strong evidence of the unconsciousness of his act.

That Ernest Partridge remembered nothing of the killing confirmed the prison doctor's diagnosis. "This attack which he had is called 'masked epilepsy' ... his acts are

\footnotetext{
${ }^{45}$ Dr Ardin-Delteil, 'L'épilepsie larvée', $L e$ Progrès Méd., 29 Dec. 1900, 3rd série, no. 52, p. 495. The lack of stealth-both in committing the crime and in the conspicuous indifference to detection-reminds the medical historian of the criminal activity attributed to the morally insane. In both cases, there is a perplexing purposelessness to the fatal action that challenged the law's central tenet of culpability: intentional behaviour.
}

\footnotetext{
${ }^{46}$ Henry Maudsley, Responsibility in mental disease, London, Henry S King, 1874, p. 166.

${ }^{47}$ Ibid., p. 334.

${ }^{48}$ OBSP, 1894-95, case 814, 12th sess., p. 1119; OBSP, 1893-94, case 612, 10th sess., p. 860.

${ }^{49}$ OBSP, 1891-92, case 225, 3rd sess., p. 415.

${ }^{50}$ OBSP, 1893-94, case 612, 10th sess., p. 860.
} 


\section{Diagnosing Homicidal Mania}

automatic ... on regaining consciousness ... [he] does not remember the things that have happened". Questioned by the judge to explain the form his disease had taken, the witness replied, "Sometimes ... instead of the fit coming on they will get homicidally maniacal ... [f]rom a criminal point of view these are the worst cases." ${ }^{51}$ On rare occasions, the connection between this hidden epilepsy and murderous fury could be made explicitly, "this is a case of impulsive homicidal mania, from masked epilepsy". ${ }^{52}$ Most often, however, the two terms were simply drawn into close proximity; it was not the relationship they bore to one another but their joint appearance that constituted the reasons for the medical inference. "Absence of recollection", "absence of motive", and "evidence of epilepsy in the family" were all cited as grounds for the inference of homicidal mania, although one suspects that absence of motive weighed heaviest for the diagnosis: "I do not think a man would have any intelligible motive for killing his brother, unless he was insane, or a very great criminal". ${ }^{53}$

Although medical witnesses at the Old Bailey had long grown accustomed to giving the reasons for their diagnosis - the "timing and placement of the crime, the demeanour following, the lack of recollection"- - they usually stepped gingerly around the implications of impaired volition for the court's business of assigning criminal responsibility. ${ }^{54}$ No such reticence inhibited medical authors. Writing in the Journal of Mental Science some twenty years before the first mention of masked epilepsy in court, a Dr Thorne Thorne of St Bartholomew's unequivocally affirmed: "Volition is in abeyance, and hence responsibility must be so also." ${ }^{55}$ The question of human agency, however, was never far from courtroom testimony regarding masked epilepsy, or homicidal mania for that matter. Convulsive behaviour commonly associated with epilepsy had long been conceptualized as patently involuntary, just as the impelling force of an overwhelming delusion could be conceived as having removed the prisoner's will. McNaughtan's own delusion of political persecution after all had supplied the London reading public with trenchant images of what it was like to be in the hapless throes of an all-consuming idée fixe. The source of aggression was clearly the delusion. For those cases of homicidal mania that were short of either delusion or masked epilepsy, there still remained its resemblance to another, very specific form of impulsive behaviour that had found success in the London courtroom.

Old Bailey juries had long been willing to consider the exculpatory potential of a defence based upon the mental upheaval following childbirth as well as related disturbances owing to

${ }^{51}$ OBSP, 1910-11, case 251, May, p. 255.

${ }^{52}$ OBSP, 1893-94, case 612, 10th sess., p. 860.

${ }^{53}$ Ibid.

${ }^{54}$ Medical witnesses could show exquisite sensitivity to the implications of their testimony, even when asked directly to comment on the prisoner's responsibility for the act. These questions could sometimes be rather indirect, but on other occasions reveal point-blank inquiry, as in the trial of Edward Oxford (1840) when the judge asked, "What is the limit of responsibility a medical man would draw?" With obvious deference to the legal forum, the medical man responded, "This is a very difficult point - it is scarcely a medical question ... it is very difficult to draw the line between eccentricity and insanity." (OBSP, 1840 , case 1877,9 th sess., p. 505).
55 Thorne Thorne, 'Masked epilepsy', J. Men. Sci., Jan. 1871, 16: 580-4, p. 583. Other voices in the medical community could be no less adamant. According to the French clinician Falret, the epileptic who, in a state of post-ictal delirium, attempted or committed suicide, homicide, or arson, "had not the slightest responsibility for "violent acts committed by him in the midst of this completely automatic, though short delirium", " "they strike mechanically, without motivations, without interest, without knowing what they do or, at least, with a vague consciousness of their actions'," quoted in Oswei Temkin, The falling sickness: a history of epilepsy from the Greeks to the beginnings of modern neurology', Baltimore, Johns Hopkins University Press, 1971, p. 321. 
reproductive biology. That beloved infants could be killed in a sudden burst of emotion even as the mother remained conscious had long been argued in court and in print. ${ }^{56}$ Although commonly associated with violent, unaccountable outbursts of homicidal fury, medical opinion regarding puerperal insanity often rested upon the presence of delusion in the tragic assault upon an infant. This association with circumscribed intellectual derangement has immediate relevance for present purposes: when puerperal mania (and other reproductively based disturbance) was combined with delusion, the prisoner was likely to be described in court as suffering from homicidal mania. "I should certainly conclude that the absence of concealment of having done the deed was an indication of homicidal mania. ... [she had] ... many delusions ... that her milk was turned to water." 57 Although criminal defences based on a range of reproductive ills did not ensure an acquittal, courtroom questioning reveals that defences based upon physiological upheaval were taken seriously and, one suspects, provided support for considering homicidal mania as another of Maudsley's "morbid states of the nervous system".

Framing insanity as a disorder of the nervous system carried obvious implications for retaining a belief in an autonomous will, already under critical scrutiny in light of emerging biological research on reflex action. These studies conceived of the organism's behaviour as serving its own physiological needs, a conviction that threatened a formal break with mind-body interaction that had supplied previous generations with a model of behavioural organization. Reflex action was patently automatic, carrying an "in-built purposesiveness [that] functioned in terms of the law of organismic self-conservation". ${ }^{58}$ With the implicit removal of the will and consciousness as things-although still sometimes present as properties of physiological organization-Thomas Laycock and William B Carpenter provided a new generation of asylum physicians and police surgeons with a model of human functioning that not only relegated mental elements to the status of epiphenomena of physiological processes, but also provided forensic-psychiatric witnesses with a compelling conception of behaviour unattended by "mental elements" such as intentionality.

The law, however, is based on just such intentional mental elements. ${ }^{59}$ It is the prisoner's conscious resolve-his will to harm-that confers culpability to action. Growing interest in reflex theory meant that the common law's conception of psychological man was increasingly spinning away from popular and scientific conceptions of what lay behind human behaviour. Sleepwalking and theatrical demonstrations of hypnotic trance revealed choreographed actions displaying no apparent consciousness or will. At the Old Bailey,

\footnotetext{
${ }^{56}$ Shelley Day, 'Puerperal insanity: the historical sociology of a disease', PhD thesis, University of Cambridge, 1985; George K Behlmer, 'Deadly motherhood: infanticide and medical opinion in mid-Victorian England', J. Hist. Med. Allied Sci., 1979, 34: 403-27; Mark Jackson, "“Suspicious infant deaths": the statute of 1624 and medical evidence at coroners' inquests', in Clark and Crawford (eds), op. cit., note 7 above, pp. 64-86. Most recently Hilary Marland has considered the incidence of cases of puerperal insanity in asylum admissions in " Destined to a perfect recovery": the confinement of puerperal insanity in the nineteenth century', in J Melling and B Forsythe (eds), Insanity, institutions and society,
}

1800-1914: a social history of madness in comparative perspective, Routledge, 1999, pp. 137-56.

${ }^{57}$ OBSP, 1856-57, case 480, 6th sess., pp. 722-3.

${ }^{58}$ Karl Danziger, 'Mid-nineteenth-century British psychophysiology: a neglected chapter in the history of psychology', in William R Woodward and Mitchell $\mathrm{G}$ Ash (eds), The problematic science: psychology in nineteenth-century thought, New York, Praeger, 1982, pp. 119-46.

${ }^{59}$ Roger Smith, Trial by medicine: insanity and responsibility in Victorian trials, Edinburgh University Press, 1981, pp. 52-3. 


\section{Diagnosing Homicidal Mania}

jurors learned of further dramatic episodes of otherness, manifested in automatism and in states of epileptic vertigo suggesting mysterious displays of unconscious though purposive action. Judges responded soberly and in temperate tones to medical assertions that such behaviour was unattended by consciousness, with the clear implication that the actor stood beyond the purposes of law in terms of ascribing culpability for harm done. For their part, juries appeared perfectly willing to consider the distance that separated act from actor.

Cases involving suspended consciousness, however, were not numerous. Judicial equanimity may well have been conditioned by the infrequency of defences engaging dissociation, and perhaps by their mesmerizing theatricality as well. These events were framed as exceptional states of "absence" or of having "gone missing"; they were not discussed in the realm of impulses. Acquitting defendants for offences committed in unconscious states of being did not therefore threaten to undermine the law's investment in intention and purposeful resolve as the defining elements of responsibility.

\section{The (New) Professional Gaze}

The court's willingness to entertain medical testimony featuring uncontrollable impulses in the form of homicidal mania can also be explained by the background of the medical witnesses who were transporting the new disease entity into the Old Bailey. The years that had witnessed the introduction of delusion as the most frequently invoked medico-legal concept at the Old Bailey (1800-43) and the controversy over moral insanity and irresistible impulse (1844-76) had also seen the predominance of asylum physicians and general practitioners in the courtroom. ${ }^{60}$ The first "mad-doctors" in court were often neighbours of the accused who happened to witness behaviour or who engaged in conversations that had taken an unexpected detour into delirious speech or frightening histrionics. These early forensic-psychiatric witnesses were likely to be employed in the (private) lunacy trade as medical attendants in large asylums, or as gaol surgeons requested by the Corporation of the City of London to visit prisoners likely to raise an insanity plea. Authors of medical texts also appeared in court, several having had no contact at all with the prisoner. ${ }^{61}$

In the first half of the nineteenth century, the most frequently appearing witness was the Newgate surgeon, Gilbert McMurdo, who almost always found the prisoner to be sane, sometimes in cases of such patently conspicuous madness that his testimony was risibly absurd. ${ }^{62}$ In the decades immediately following McNaughtan, it was the asylum doctors whose voluble presence was most noteworthy, taking issue specifically with questions that

${ }^{60}$ For a survey of pre-trial associations between medical men and prisoners before 1843, see Eigen, op. cit., note 4 above, pp. 120-32.

${ }^{61}$ Forbes Winslow, testifying at the McNaughtan trial, is perhaps the best example of this. Winslow makes repeated appearances at the Old Bailey, often visiting prisoners prior to the trial. Another author, Arthur Luff, referred to a book of his while testifying (not named, but likely to be his Text-book of forensic medicine and toxicology, London, Longmans, Green, 1895) as well as his visit to prisoners in their cells, giving both as the grounds for his courtroom opinion. Luff's volume is also referred to by prison doctors in their testimony.

${ }^{62}$ With adamantine insistence, McMurdo famously refused to find anything aberrant in the account of the ship's captain, Noah Pease Folger, who, at the mention of his supposed enemy's name, stripped off his clothes, broke windowpanes with his bare fists, danced a jig on the broken glass, and completed the display by jumping bareback on a passing whale. Denying the existence of "any symptom which he has exhibited to make me come to the conclusion of his being of unsound mind", McMurdo's opinion stood alone. OBSP, 1833, case 815, 4th sess., p. 402. 


\section{Joel Peter Eigen}

Table 2

Professional affiliations

\begin{tabular}{lccc}
\hline Place of employment & Surgeon & Physician & "Medical Professional" \\
\hline Prison & 2 & 15 & \\
Gaol & 4 & & \\
Police & 8 & 3 & \\
Asylum & 1 & 6 & \\
Hospital & & 1 & \\
"Lecturer" & 4 & 3 & \\
Private practice & & & \\
None specified & & & \\
\hline
\end{tabular}

precluded witnesses from venturing into the territory of volitional impairment, exclusive of delusion. ${ }^{63}$ Gaol surgeons continued to find prisoners sane; privately retained asylum doctors and general practitioners were likely to divine substantial mental impairment. In the latter part of the nineteenth century, however, one sees a shift in the professional background of the medical witnesses and the venues that served to bring together the prisoner and the medical man. Table 2 provides data on the fifty courtroom appearances of the medical witnesses who appeared in the forty-three trials that featured testimony on homicidal mania and masked epilepsy.

When homicidal mania and masked epilepsy were introduced to the Old Bailey, it was not the asylum superintendent or the specialist in mental medicine but the prison doctor and police surgeon who were most likely to argue its presence. Whether it was their unambiguous affiliation with the Crown or their long familiarity with the Old Bailey-many of these men had testified in multiple trials during these years-their appearance in court sparked neither a sharp rebuke by the judge nor hostile questioning from the prosecuting lawyer. Further, although divisional surgeons and prison medical officers had been directed to see the defendant for the express purpose of giving testimony in court, they were just as likely to affirm the presence of insanity as to deny it. Clearly, medical men had found a professional voice independent of their employer, and this was also true of physicians and surgeons privately retained by the defence.

Directly associated with the shift in professional background is the forum that introduced the prisoner to the eventual witness. By the end of the nineteenth century, the two most frequent associations grew out of the prisoner's encounter either with the police surgeon, called to the scene of a crime to determine the extent of the victim's injuries and happening to observe the assailant displaying signs of emotional aberrancy, or in an interview with the prison's medical officer or an established London physician, requested by the Treasury to speak with the defendant. Indeed, the prison interview was fast replacing all other forums for

\footnotetext{
${ }^{63}$ Responding to the prosecuting attorney's insistence that he address the prisoner's intellectual capacities, John Conolly replied testily, "I am perfectly aware that is the question." The judge interrupted, "If that is the question, it can surely be answered?" to which the medical witness answered,
}

"I do not think it can absolutely be answered: I think it
can only be answered in the manner in which I have
answered it." The doctor's preferred focus was the
prisoner's "power of controlling or resisting a train of
thought tending to criminal actions". OBSP, 1850-51,
case 1502, 9th sess., pp. 368-9. 


\section{Diagnosing Homicidal Mania}

the initial contact between prisoner and medical man. Although it is also true that Surgeon McMurdo of Newgate had frequently appeared in insanity trials earlier in the century, he had no particular expertise in mental medicine. His biography in the Royal College of Surgeons lists an expertise as ophthalmology, but no mention of his employment as surgeon to Newgate.

In McMurdo's place, the latter years of the century witnessed prison medical officers who not only displayed a curiosity about the derangement that often led to a discovery of insanity, but who transported a host of new diagnoses into the court as well. To be sure, they were not the only purveyors of new terms. Henry Maudsley, Forbes Winslow, and Henry Charlton Bastian, whose institutional base was a general, not a mental, hospital, were also on hand. The suspicion that attended an early-nineteenth-century mad doctor "trying to get someone off on insanity" did not greet the medical men who proffered the existence of homicidal mania in the late nineteenth century. ${ }^{64}$

\section{A Mania to Diagnose}

The opportunity to track and quantify the emergence of an innovative diagnosis in courtroom testimony understandably tempts the medical historian to suggest the arrival of a pivotal moment in the evolution of forensic psychiatry. A parallel temptation lurks in the opportunity to compute acquittal rates in insanity trials, presumed to reveal the influence of expert testimony on the jury. Vivid as they may appear, jury decisions displayed in the aggregate promise rather more than they deliver. One would be hard pressed to explain any one verdict by the introduction of a novel medical term or the participation of specialist witnesses. Then as now, verdicts are driven by a range of factors likely to elude the most dogged of detectives. Even if the full range of forces behind a particular acquittal was ultimately retrievable, one needs to remember that the legal significance behind the jury's finding was shifting as well; the criterion for a successful plea changed qualitatively from "total insanity" in the late 1700s to a range of partial insanities that gained exculpatory potential by the mid-1800s. Clearly, changes in insanity's meaning provide the critical context for examining any quantitative change in acquittal or medical participation rates.

The same caveat regarding context applies to the hazards of quantifying diagnostic terms that emerge in medical testimony. "To the great despair of historians," Marc Bloch trenchantly observed, "men fail to change their vocabulary each time they change their customs." 65 It was the custom of medical witnesses from the 1850 s onward to employ homicidal mania to typify the explosion of sudden, uncontrollable, and unreflective impulses. But the forces believed to animate the fateful outbursts changed materially over the course of the century. Originally depicted as irresistible, autonomous impulses stemming from unknown origins and finding singular expression in murderous assault, these mysterious forces had, by the early 1900s, found an altogether more knowable home in delusion-a thoroughly

\footnotetext{
${ }^{64}$ For an overview of judicial attitudes, which sometimes could find sharp expression-“"Haven't you been here before, as a Jew physician, trying to get someone off on insanity?"- -see Eigen, op. cit., note 4 above, pp. 55-7. The foregoing sentiment was anomalous; with the exception of insanity defences
} 
familiar forensic phenomenon - or in a novel form of epilepsy, a staple of nineteenth-century courtroom testimony. Initially dismissed as a diagnosis suspicious at best and "dangerous" at worst- "Gentlemen, such a thing as a person not being able to control himself in the doing of an act which he knows to be wrong is a phrase that is not known to the law of this country"-homicidal mania eventually enjoyed temperate, solicitous inquiry as it grew to prominence in late Victorian courts. ${ }^{66}$ Although the term stayed familiar, the context in which it was invoked shifted qualitatively.

The gentlemen addressed in the quotation above were members of a jury charged with determining the fate of defendants such as Mary Ann Brough, who faced trial in 1856 for slitting the throats of her six children. Prior judicial opinion that a "knowing but uncontrollable impulse was unknown to the common law" played a central role in the judge's instructions to the jury. According to most members of the mid-Victorian bench, an insanity of affect, of defective emotional control, of an inability to restrain an impulse the defendant knew to be wrong was categorically beyond the common law's meaning of insanity. The judge's instructions in the Brough trial were made in response to the testimony of Forbes Winslow, a prominent author and well-known London medical man, who had described the defendant's mental impairment as "a combination of suicidal and homicidal mania, frequently combined, both arising from a disordered brain". Although Winslow spoke only in terms of a homicidal (not an uncontrollable) impulse-a point underscored by the Lancet in its review of the case-the trial judge rejected the notion of an uncontrollable impulse tout court. This was, the judge averred, "a most dangerous doctrine, for undoubtedly every crime is committed under some impulse and the object of law was to control impulses of that description and thus prevent crime". ${ }^{67}$

In response to the public controversy that followed the mother's acquittal, James Fitzjames Stephen sought to clarify the role of the jury in future insanity trials. Speaking to the Juridical Society in 1858, the noted jurist acknowledged — without derision- the possibility of an uncontrollable impulse, but shifted the jury's attention away from the characteristics of any particular disease to the events surrounding the particular crime: "Guilt turns upon the wilfulness of the act, and not upon the sanity of the prisoner." ${ }^{\prime 68}$ It is important to see Stephen's formulation not as some juristic sleight of hand; he is not consigning the prisoner's psychological state to tertiary significance but rather insisting that whatever the purported impairment in cognitive, or indeed, emotional faculty, the court's business was to consider the prisoner's actual behaviour in committing the alleged act. Stephen is underscoring the law's foundational investment in mens rea: what the actor thought he was doing at the time. Medical testimony proffering hypothesized mental states could certainly inform this inquiry, but diagnoses in themselves were not dispositive. Uncontrollable impulses may exist (in theory), but the jury in a particular case must determine the prisoner's culpability by focusing upon his or her actions at the time of the crime. Given the events of the day, was it likely the accused acted with intention: was the behaviour wilfully chosen?

\footnotetext{
${ }^{66}$ Smith, op. cit., note 59 above, p. 111.

${ }^{67}$ Roger Smith, 'Defining murder and madness; an introduction to medicolegal belief in the case of Mary Ann Brough', in R A Jones and H Kulick (eds),
}

Knowledge and society: studies in the sociology of culture past and present, 4 vols, Greenwich, CT, JAI Press, 1983, vol. 4, pp. 173-225, on p. 197.

${ }^{68}$ Ibid., p. 209. 


\section{Diagnosing Homicidal Mania}

Almost half of the medical witnesses in subsequent trials answered Stephen's question by invoking the defendant's delusion. Although one might think that only with difficulty could a prisoner be described as clear thinking and delusional, prisoners pleading a delusional insanity from 1800 had argued, often successfully, that at the time of the crime their behaviour had been placed beyond their control. Trial testimony suggested an involuntary action: an impelling, insistent spur to (criminal) action dictated by delusory belief. What did it mean to 'know' the nature and quality of one's acts when delusory fear impelled action? It was more than a little disingenuous, therefore, for the judge to state with such apodictic insistence that an uncontrollable act knowingly committed was "unknown" to the law of the country. It had been known at the Old Bailey for more than half a century.

No one had to articulate epilepsy's involuntary features: does anyone choose to foam at the mouth and collapse in a convulsive seizure? Epilepsy's entrance into courtroom testimony did not have to wait for its masked variation in the 1890 s or even its vertiginous form in 1876. Apoplectic and epileptic fits had played a role in insanity trials since the beginning of the nineteenth century, although they were more likely to be invoked by neighbours, lovers, and co-workers than medical specialists. ${ }^{69}$ This easy elision of epilepsy with insanity would come under close scrutiny once large-scale asylum research, undertaken in the second half of the $1800 \mathrm{~s}$, led to the conclusion that the incidence of mental problems among the epileptic population was very small. ${ }^{70}$ The conceptual separation of epilepsy from insanity helped to shift the study of epilepsy away from psychiatry and into neurology's preserve, a development that gained strength over the course of the later 1800s. Not all psychiatrists, however, were willing to surrender epilepsy to the neurologist. With the conceptual substitution of mental impulsion for gross motor disturbance, medical men at the Old Bailey (and in print) invoked unique professional experience to proffer explanations for sudden, often inexplicable homicidal assault. When judges and juries were confronted with this novel substitution for the familiar behavioural histrionics, courtroom inquiry focused upon the nature and features of masked epilepsy, not its preposterousness. The Old Bailey was inquisitive, not dismissive.

For the historian of law and medicine, this was a signature moment: "loss of control" had arrived on a forensic-psychiatric footing that met neither judicial suspicion nor derision. With the Victorians' increasing proclivity to cast all questions of human conduct in physiological terms, two of the most vexing forms of social pathology-criminality and mental derangement-were conceived as the fearful triumph of impulses over weakened volition. The organism's sovereignty over such untoward emotional and physical urges had been achieved through the process of inhibition, acting both as a physiological mechanism mediating among impulses and as a cultural force, suppressing untoward asocial impulses. ${ }^{71}$ When the powers of inhibition were barred by organic alterations in the brain, however, the organism - and by extension, the social fabric_-was left prey to brutish, violent, impetuous impulses.

${ }^{69}$ Eigen, op. cit., note 4 above, pp. 82-107.

${ }^{70} \mathrm{G}$ E Berrios, 'Epilepsy and insanity during the early nineteenth century', Arch. Neurol., Sept. 1984, 41(9): 978-81.

\footnotetext{
${ }^{71}$ Roger Smith, Inhibition: history and meaning in the sciences of mind and brain, University of California Press, 1992.
} 


\section{Joel Peter Eigen}

In the late nineteenth century, there was no shortage of scientific explanations to account for defects in the brain's development (and by extension, the lamentable failure to inhibit asocial forces seething just below). Given the era's preoccupation with the toll that unchecked impulses could exact, it is of more than passing interest that degeneration theory-focusing on the morbid deviation from normal development - and masked epilepsy were advanced by the same theorist. According to Morel, the morbid phenomena associated with degeneracy could find expression in mania, "dangerous" epilepsy, dementia, idiocy or imbecility, and could change over time. ${ }^{72}$ Degeneracy could be manifested in insanity in one generation, criminality in the next, and epilepsy in the third. ${ }^{73}$

Epilepsy of course did not have to wait for degeneration theory to give it organic grounding; neurologists had long maintained that epileptic seizures were traceable to cerebral lesions, although none had ever been successfully isolated and identified. ${ }^{74}$ Morel's focus was not epileptic lesion but epileptic character: an irritable, menacing, and, at its most extreme, homicidally maniacal disposition. Much like the insane and the criminal, the masked epileptic revealed the effects of corrosive, degenerative forces resulting in a loss of control over thought and action. In sum, degeneracy theory provided late-nineteenthcentury deviance theorists with an explanation of how morbid deviation in an organism's heredity could result in the loss of its powers to inhibit violent impulses.

The failure to inhibit asocial impulses also found expression in evolutionary theory. Complementing degeneration's notion of morbid character, evolutionary theorists spoke of epileptics as a class that, like the criminal, revealed fateful developmental arrest. Together with the insane, who had also been consigned to a lower evolutionary plane, the epileptic revealed not the backward slide of the degenerate but the simple failure to have evolved to a fully adult plane. For those who pursued a connection between inhibition and evolution, the fact that the epileptic, the criminal, and the insane acted on impulse was hardly a mystery. Dissipated habits or feckless forebears had not destroyed moral character; the elevated sentiments had simply never been achieved.

Although degeneration and evolutionary theorists addressed different reasons for the deviant's mental and social state, ideas central to both could be invoked to explain any and all forms of nineteenth-century social pathology. Maudsley, in particular, collapsed developmental and hereditarianism defect: "[T]his criminal class constitutes a degenerate or morbid variety of mankind, marked by peculiar low physical and mental characteristics ... stupid, sullen, sluggish, deficient in vital energy, and sometimes afflicted with epilepsy." 75 Given the trenchant images put forward by degeneration and evolution, one might conclude that the eventual acceptance of homicidal mania in the late-nineteenthcentury courtroom was if anything overdetermined: no matter where one looks, powerful cultural beliefs framed the mentally, behaviourally, and legally wayward as the lamentable result of failed development—prey to basic, unsocialized impulses—and, in consequence,

\footnotetext{
${ }^{72}$ Bénédict-Augustin Morel, Traité des dégénérescences physiques,

intellectuelles et morales de l'espèce humaine, Paris, J-B Baillière, 1857, p. 77.

${ }^{73}$ Morel's ideas were embraced by Maudsley, op. cit., note 46 above, p. 337.
}

\footnotetext{
74 "Let us admit frankly [Esquirol asserted] that ... pathological anatomy has shed little light on the immediate seat of epilepsy." Quoted in Temkin, op. cit., note 55 above, p. 273.

${ }^{75}$ Maudsley, op. cit., note 46 above, pp. 29-30.
} 


\section{Diagnosing Homicidal Mania}

profoundly ill-equipped to meet contemporary expectations of self-control and thus to merit the ascription of criminal culpability. Almost overdetermined.

It was not, after all, Morel's Traité des dégénérescences or Lombroso's L'Uomo delinquente but successive editions of A S Taylor's Principles and practice of medical jurisprudence that lawyers brandished in the courtroom. Although expressions such as "loss of voluntary control" were standard courtroom fare, one will look in vain for unambiguous allusions to degeneracy or evolution in forensic psychiatric testimony. That Charles Darwin, Herbert Spencer, and Cesare Lombroso influenced juristic attitudes regarding the emerging medical conceptions of impulsive criminality may well be assumed, of course. After all, one could hardly construct an evolutionary history of medico-legal debate without evolution, and yet one simply does not know what jurists and jurors were reading, listening to, or discussing among their cohorts. The temptation to write history in terms of what courtroom actors must have been thinking is particularly hazardous when confronted with the ubiquitous tropes of evolution and degeneracy in contemporary recreations of the Victorian era's rolling social debate.

This caveat is not meant to question the importance of situating historical actors in their moment and cultural space, but to suggest that the penetrating influence of historical moment and cultural space may be local as well as national. The English courtroom had a history and a legal culture very much its own. Beginning with testimony invoking moral insanity in the mid-1800s, the Old Bailey had repeatedly faced the riddle of how and when to assign culpability to seemingly inexplicable criminality: mothers destroying beloved infants, eminently reasonable persons killing their best friends, devoted spouses assaulting loving partners where no history of animus or indeed even a precipitating incident had obtained. Such events challenged the tenets of the common law's construction of psychological man: a sentient being capable of understanding the nature and consequences of his acts, and, by dint of this knowledge, able to inhibit the sway of unruly impulses. To accept the existence of autonomous, impelling, unreflective impulses threatened to undermine a normative standard of mental and behavioural functioning without which no assignment of moral responsibility was possible. Still, the morally insane-however defined or characterized-were ubiquitous in the medical literature and on occasion, in court.

Testimony gleaned from the Old Bailey Sessions Papers suggests that homicidal mania gained acceptance in the late nineteenth century because it permitted the law to lodge the inexplicable, perhaps even purposeless, murder in the sanctioned legal exception of delusion or in a new species of a long-standing disease. By their calm questioning and inquiring demeanour, jurists reveal no perceived threat to the sovereignty of legal culture over its own world. If there was a role for evolution and degeneracy in the courtroom's acceptance of homicidal mania, it was in those cases when a defence rested on masked epilepsy, with the criminal assault serving as a substitute for the physical convulsion.

But even this nod at physiological upheaval was not a case of jurisprudence ceding conceptual territory to an all-consuming scientific/social trope. The history of forensic psychiatry is, first and foremost, the history of law. Armed with innovative terms, medical men may have flooded the late-Victorian insanity trial with behaviourally consequential diagnoses, but, to be successful, their testimony had to engage the common law's chosen 


\section{Joel Peter Eigen}

derangement: delusion. When the prisoner evinced no cognitive error, a mental convulsion equivalent to an epileptic spasm could address the issue of volition. The late-Victorian court would permit impulse no independent berth: there would be no autonomous home for blind drives lodged in the passions. For "loss of control" to share testimonial billing with an "inability to know the nature and consequences of one's acts", the physician's testimony had to await a forensic-psychiatric diagnosis that by its name and associated imagery revealed a rare moment when legal and medical psychology saw the same defendant in the dock. 